\title{
Superweed amaranth: metaphor and the power of a threatening discourse
}

\author{
Florence Bétrisey $^{1}$ (D) . Valérie Boisvert ${ }^{1}$ iD $\cdot$ James Sumberg $^{2}$ (D)
}

Accepted: 10 August 2021 / Published online: 9 September 2021

(c) The Author(s) 2021

\begin{abstract}
This paper analyses the use of metaphor in discourses around the "superweed" Palmer amaranth. Most weed scientists associated with the US public agricultural extension system dismiss the term superweed. However, together with the media, they indirectly encourage aggressive control practices by actively diffusing the framing of herbicide resistant Palmer amaranth as an existential threat that should be eradicated at any cost. We use argumentative discourse analysis to better understand this process. We analyze a corpus consisting of reports, policy briefs, and press releases produced by state extension services, as well as articles from professional and popular magazines and newspapers quoting extension specialists and/or public sector weed scientists or agronomists. We show how the superweed discourse is powered by negative metaphors, and legitimizes aggressive steps to eradicate the weed. This discourse reinforces the farmers' techno-optimism master frame, contributes to deskilling of farmers and sidelines ethical concerns.
\end{abstract}

Keywords Amaranth $\cdot$ Herbicide resistance $\cdot$ Superweed $\cdot$ Metaphor $\cdot$ Critical discourse analysis

$\begin{array}{ll}\text { Abbreviations } \\ \text { GM } & \text { Genetically modified } \\ \text { GMO } & \text { Genetically modified organism } \\ \text { HRPA } & \text { Herbicide resistant Palmer amaranth } \\ \text { IPM } & \text { Integrated pest management } \\ \text { PA } & \text { Palmer amaranth } \\ \text { US } & \text { United States }\end{array}$

\section{Introduction}

The first evidence of herbicide resistant weeds emerged in the 1950s (Hilton 1957), and by 2018, 299 species had been reported to be resistant to the herbicide glyphosate ${ }^{1}$

Florence Bétrisey

Florence.betrisey@unil.ch

Valérie Boisvert

Valerie.boisvert@unil.ch

James Sumberg

j.sumberg@emeritus.ids.ac.uk

1 Institute of Geography and Sustainability, Faculty of Geosciences and Environment, University of Lausanne, CH-1015 Lausanne, Switzerland

2 Institute of Development Studies, University of Sussex, Brighton BN1 9RE, UK
(Heap 2021). Palmer amaranth (Amaranthus palmeri) (PA), which is native to the southern areas of North and Central America, including Mexico, California and Texas (Ward et al. 2013), is one of these resistant species. PA grows well in both degraded and nutrient rich soils, and is resistant to drought (Alemayehu et al. 2015). It has been described as having "invasive tendencies and a history of range expansion" (Ward et al. 2013, p. 12), but historically it was not considered a particularly "troublesome" weed (Ward et al. 2013, p. 12) before becoming resistant to glyphosate. Like some other herbicide-resistant weeds, herbicide-resistant PA (HRPA) has been identified in the media as a "superweed" (Dodrill 2015; Gallant 2013; Kistner 2018), a term that is commonly used to refer to weeds that have developed resistance to one or more major herbicides and are therefore difficult to control. ${ }^{2}$ Ironically, other species of amaranth have been labelled as "superfood" because of their nutritional

\footnotetext{
$\overline{1}$ Glyphosate is a broad-spectrum systemic herbicide that was brought to market for agricultural use by the Monsanto Corporation in 1974 under the trade name Roundup.

${ }^{2}$ In April 2015 the Weed Science Society of America joined with six sister organizations to recommend a new definition for superweed: "Slang used to describe a weed that has evolved characteristics that make it more difficult to manage due to repeated use of the same management tactic. Over-dependence on a single tactic as opposed to using diverse approaches can lead to such adaptations" (https://wssa. net/2015/04/weed-scientists-offer-new-definition-for-superweed/, last accessed 12 July 2021).
} 
qualities (Bruce 2014; Gullón et al. 2016; Milner 2015), and the "rediscovery" of superfood amaranth has been portrayed as an important opportunity for both producers and consumers (Bétrisey et Boisvert 2020).

Since the 2000s HRPA has become common in fields of genetically modified (GM) soybean and cotton in the United States (US). Farmers have used a range of practices against this weed, including burning, tilling and herbicide cocktails (mixtures of various herbicides), with important consequences for humans and the environment (Flitter 2017). Monsanto developed its own solution to the resistance problem - a soybean variety resistant to a broad-spectrum herbicide called dicamba.

The importance of framing - whether in the discourses of consumer and environmental advocacy groups, agriculture and biotech companies, or government regulatory bodies and farming organizations - has already been demonstrated in relation to the "superweed problem" (Bain et al. 2017; Dentzman 2018). These authors highlight a process of "naturalization" of the problem by proponents of genetically modified organisms (GMOs), who, by asserting that herbicideresistance is a natural process and not specific to GMOs, sought to "scale-down" the responsibility for the emergence of superweeds to local farming practices and specifically the overuse of glyphosate. Conversely, critics of GMOs sought to "scale-up" responsibility to global economic structures, agro-chemical companies and government bodies that all encouraged farmers to convert to cropping systems reliant on GMOs and glyphosate. Here farmers are framed as being "stuck on a chemical treadmill" (Faber 2017), ${ }^{3}$ and forced to turn to GM seeds and herbicides. Bain et al. (2017) show how these framings influence divergent efforts to address the spread of superweeds: for example, by developing new herbicides and herbicide-resistant seeds, or through fundamental structural reform of the whole agricultural sector.

Dentzman (2018) argued that US farmers share a "technooptimism master frame", where a master frame constitutes a "culturally resonant, general, symbolic repertoires of interpretation that are drawn upon by a variety of actors to identify problems, specify grievances, and justify goals", providing a "tool box from which interpretations can be drawn in order to understand or justify certain situations and actions" (p. 119). The techno-optimistic orientation of this master frame suggests that "technology is viewed as the solution but never the cause of the problem" (p. 121).

\footnotetext{
3 The term "treadmill" was used first by McAfee (2003) in reference to the structural relationships driving chemical use in agriculture, although the notion of a "technological treadmill" in agriculture, describing the cycle of improving technology, reducing the cost of production, and increasing farm sizes was first described by Willard Cochrane (1958).
}

In the case of herbicide-resistant weeds, this master frame manifests itself as faith in continued development of new herbicides. In this paper we use discourse analysis to better understand the power that this master frame exercises over farmers and their approach to the problem of herbicide-resistant weeds. Drawing on Argumentative Discourse Analysis (Hajer 2006, 1995) and the work of Breeze (2017), Larson (2005) and Nerlich (2009), we pay particular attention to the use of rhetorical tools, like metaphor, that "guide the production of discourses, and hence, the dynamics of knowledge" (Maasen and Weingart 2000, p. 28). The use of metaphor, where a "descriptive word or phrase is transferred to an object or action different from, but analogous to, that to which it is literally applicable" (Oxford English Dictionary) is central to superweed discourse. For example, HRPA is described as a diabolical enemy, a fierce scoundrel that can only be defeated through an aggressive war in which farmers are on the front line. We are particularly interested in how these linguistic features help "manufacture consent" among those on the receiving end of superweed discourse (Stibbe 2001, p. 147), which portrays HRPA as an existential threat that must be eradicated at any cost. The techno-optimism master frame is critical in enabling the manufacture of such consent.

Many weed scientists within the public agricultural extension system downplay the term superweed because it suggests weeds are involved in active resistance. They are also hesitant about herbicides like dicamba because its volatility allows it to spread to neighboring, untreated crops and the nearby environment. However, our analysis shows how, together with the media, these same scientists have promoted superweed discourse despite the fact that it reinforces the techno-optimism master frame, side-lines ethical concerns, and contributes to a further deskilling of farmers. Our focus throughout is on scientists within the public agricultural extension system. This is the first step of a broader research program aiming to highlight the political nature of knowledge production within agronomy (Sumberg 2017; Sumberg et al. 2014) by focusing on its discursive dimension. We consider the case of HRPA to be "emblematic" (Hajer 2006) or representative of the politics of knowledge in contemporary agricultural science.

The paper proceeds as follows. In the next section we introduce the conceptual framework for our analysis of superweed discourse. This includes a reflection on "framing" processes and storylines inspired by Argumentative Discourse Analysis (Hajer 2006), supplemented by a review of the use of rhetorical instruments of the metaphoric type, particularly within political ecology (Larson 2014; Larson et al. 2016; Tassin and Kull 2012). Following this we present the methodology for constructing and analyzing our corpus as well as the historical-political context in which the discursive material was produced. We then present the 
results of the analysis, highlighted the role of different discursive elements in the construction of the superweed crisis. In the final sections, we discuss the results and show how the superweed discourse appears to offer new legitimacy for agricultural extension and weed science in a particularly challenging context (Liebman and Raskin 2016; Ward et al. 2014), while at the same time contributing to a process of "deskilling" of farmers (Bell et al. 2015; Fitzgerald 1993). Second, we highlight the potential effect of the discourse, and the promotion of "radical solutions" to address superweeds, on weed research and management, as well as on broader human and non-human communities.

It is important to recall that while focusing on the discursive structures around superweeds we do not seek to deny or diminish the very real environmental and economic effects of HRPA. Indeed, we recognize that herbicide resistance poses significant challenges to mainstream agriculture. The question lies more in "how one makes sense" of superweeds (Hajer 2006, p. 66), the role of framing in this sensemaking, implications for the solutions that are put forward, and their social, ecological and political effects.

\section{Conceptual framework}

Argumentative discourse analysis considers framing as a strategic process whereby political actors "aim to create necessities for (specific) policy intervention" (Leipold and Winkel 2016, p. 36). The result is the discursive production of a storyline: "a condensed statement summarizing complex narratives, used by people as 'short hand' in discussions" (Hajer 2006, p. 69). These storylines also entail discursive de-legitimation of some agents and discursive exclusion through "active fore-closing or passive non-reference to a specific agent, problematization or policy solution" (Leipold and Winkel 2016). Actors who share "the usage of a particular set of story lines over a particular period of time" (Hajer 2006, p. 70) form a "discourse coalition" (Hajer 1995). These coalitions are dynamic and often short-lived: coalition members are not "necessarily orchestrating or coordinating their actions" nor do they share deep values (Hajer 2006).

Framing of environmental issues has long been studied within political and media discourse as well as in scientific discourse (Forsyth 2003; Goldman et al. 2011; Turnhout 2018). Political ecology and those who have taken a political approach to agricultural research, for instance, have questioned the framings that help legitimate and prioritize certain research topics or approaches over others (Andersson and Sumberg 2017; Sumberg et al. 2013; Fairhead et al. 2012) and how, at a certain point, some frames prevail over others because they align better with dominant political and economic interests (Turnhout 2018; Westengen et al. 2018). Some scholars consider that scientists actively construct frames that are central in the creation of epistemic communities (Andersson and Sumberg 2017; Turnhout 2018). The latter differ from discursive coalitions in that they are longer term and contribute to researchers' identity construction and socialization, as well as the foundations of the discipline. The result is that certain research topics, approaches and directions are excluded and underlying power relationships remain unquestioned (Kull 2018). Secondly, these scientific actors might themselves have an economic interest in seeing their framing validated by political actors if it translates into, for example, new funding opportunities. Finally, in part due to the authority attributed to scientific discourse, when scientists frame a specific problem they also contribute to making it real, especially when the framing is diffused and amplified by the media (Breeze 2017).

The process of framing of environmental and, in our case, agronomic issues thus involves scientists, politicians, media and civil society producing and diffusing discourses that legitimize or delegitimize certain problems and/or solutions. However, all the discourses around a particular issue do not enjoy the same visibility. We posit that while superweed discourse is underpinned by entrenched economic interests, it is powered by rhetorical tools and linguistic features that help it "become part of the legitimizing common sense", and thus hegemonic (Chiapello and Fairclough 2002, p. 194). Linguistic features such as vocabulary, grammar and figures of speech can "reveal hidden ideological assumptions on which discourse is based" (Stibbe 2001) but they also play a key role in the "manufacturing of consent" (Stibbe 2001, p. 147) among receivers of the discourse. Questioning the use of metaphor in this process does not mean denying its utility in communication, nor does it mean advocating for metaphor-free discourses. Rather it aims at taking seriously the danger of the naturalization of particular metaphors, the possible confusion between the conveyed image and the "reality" that it is meant to represent (Tassin and Kull 2012), and the fact that constant use of negative metaphors not only limits management options but also research directions (Kull 2018).

Inspired by political ecologists working on discourses about invasive plants ("environmental weeds") (Bach and Larson 2017; Kull 2018; Larson 2014, 2005; Tassin and Kull 2012), as well as others working on discourses around climate change (Koteyko et al. 2010), infectious disease and "superbugs" (Larson et al. 2016; Nerlich 2009), we will first consider the use of metaphor within scientific and agricultural media. Following Maasen and Weingart (2000, p. 20), we define metaphor as "ideas, models, concepts or theories that have been transposed from their original discipline to another, or from the science to non-scientific subsystems or everyday discourses and vice versa". The use of metaphor can be "decorative, entertaining, or persuasive" (Maasen and Weingart 2000, p. 20). Metaphor in both social and natural 
science discourse has long been regarded with skepticism (Maasen and Weingart 2000), mostly due to these multiple functions and the various strategies that guide its use.

The cognition function makes the use of metaphor appear as a "heuristic device crucial for creation and conceptualizing novel ideas and new knowledge" (Keulartz 2007, p. 27). The discursive function, linked to entertainment and decoration, make it a "very useful" tool (Maasen and Weingart 2000 , p. 25) with which to communicate and "negotiate" scientific discourse (Keulartz 2007), while at the same time making it appear more "emotional" (Breeze 2017). Now that scientists in many fields are expected to write policy briefs and press releases that constitute specific "genres" to which metaphor is central, the communication function of metaphor merges with "promotional or even sensationalising functions" and with "the need to attract attention and persuade the audience" (Breeze 2017, p. 71). Some scholars have shown that metaphors can also be used "unconsciously, as their normalization has made them unavoidable (Bach and Larson 2017, p. 562). Nevertheless, the use of metaphor not only makes discourse more attractive, but can also "affect how we perceive and manage" the issue to which they refer (Bach and Larson 2017, p. 561). Indeed, metaphors resonate with specific "institutionally established discourse" (Maasen and Weingart 2000, p. 21) because they "call on a stock of shared pre-discursive frames" (Vicari 2015, p. 24, pers. trans.) and conversely, "impregnate with particular values the concepts to which they refer" (Tassin and Kull 2012, p. 406, pers. trans.). In this way, metaphors "entangle scientific facts with social values" (Larson 2014, p. i) which leads us to the normative functions of metaphor, which "not only determine our thinking and talking, but also our acting" (Keulartz 2007, p. 28), and "guide the [...] dynamics of knowledge" (Maasen and Weingart 2000, p. 28).

Further, Nerlich notes that the normative effect of metaphor is hard to predict and that "metaphors intended to persuade policy makers and the public, may also dissuade and demotivate" (Nerlich 2009, p. 577). All these functions make metaphors "key framing devices" (ibid), which the analyst can use to illuminate hidden discursive structures, which is the core aim of discourse analysis (Hajer 2006).

\section{Methodology}

We collected and classified a number of reports, policy briefs, and press releases produced by state extension services, as well as articles from professional and popular websites, magazines and newspapers. To identify these sources, we used a series of keywords ("palmer amaranth", "palmer pigweed", "superweed amaranth", "superweed pigweed", "amaranth Monsanto") to search using Google. The identified texts were then screened to detect those that were substantially about PA and that cited extension and/ or public sector weed scientists or agronomists. This led to a heterogenous collection of 56 texts, published between 2008 and 2018, including: 20 from professional agricultural magazines and newspapers (eight of these were published by the Farm Progress Group); 14 from state agricultural universities and extensions services; six from US national outlets; six from US regional outlets; and ten from international outlets (Appendix See Table 3).

Regional media and outreach texts in the collection originated from 16 states located in the Midwest and its southeast frontier. ${ }^{4}$ Scientists from Iowa State University Extension and Outreach are the most frequently cited in media (18 times), followed by University of Arkansas (11), University of Illinois (6) and University of Georgia (6). The most cited expert overall (in 11 texts) is an extension scientist at Iowa State University. The term "superweed" appears exclusively in texts from media outlets, it does not appear in any of the extension texts.

The collection of texts is heterogeneous in terms of both "genre" and "style" (Fairclough 2013), which can make analysis difficult. Indeed, the newspaper articles are written very differently from the extension materials. National and international media also differ from professional magazines in terms of style. However, this heterogeneity is also symptomatic of the diffusion of superweed discourse, and more generally of hybrid scientific controversies that involve different actors, scales and "genres" (Foyer 2010). When speaking through extension publications or professional magazines, extension scientists seek to transfer knowledge and influence farmers' practices, while they appear to use the general media to fulfill their role as advocates for the farming community.

The selected texts were coded manually, using atlas.ti software. An iterative process was used with the first coding round being conducted deductively, specifically searching for problem framings, storylines and any use of metaphor. Several metaphors were identified from this first round, and these were then grouped together in different registers (medical, war, diabolic, etc.). We then screened the corpus again looking for other instances of these metaphors and registers.

Storylines - like that of the origin of HRPA - were identified inductively through a first reading of the texts. A second reading was used to identify the various elements of the storylines. Informed by discourse analysis (Hajer 2006; Chiapello and Fairclough 2002) we were interested in how these elements worked to legitimize certain actors and solutions while making others invisible. Finally, we also screened the

\footnotetext{
${ }^{4}$ North Dakota, South Dakota, Nebraska, Kansas, Minnesota, Iowa, Wisconsin, Illinois, Michigan, Ohio, West Virginia, Pennsylvania, Kentucky, West Virginia, Pennsylvania.
} 
corpus looking for other rhetorical devices such as normative and prescriptive statements that, together with metaphors, empower the storyline, and motivate readers to undertake the prescribed actions (Chiapello and Fairclough 2002). Such statements are most often associated with modal verbs such as "should", "must" or "have to", and the imperative tense.

The literature on Palmer amaranth and superweeds is very large and highly heterogeneous. The key threat to the internal validity of this study is linked to the relatively small corpus analyzed. Nevertheless, we have no reason to believe there was systematic bias in selecting the texts, or that they do not adequately represent the larger body of US extension publications and largely professional media in which we were interested.

\section{Public agricultural extension and the media}

Public agricultural extension services from a variety of states have been involved in both research on and management of the problem of herbicide resistant weeds. In the case of HRPA, extension agronomists and weed scientists help farmers to identify it and find appropriate "eradication" methods (Sparks 2014). They also advocate for farmers struggling with HRPA.

State land-grant universities were established in the midnineteenth century through the Morrill Act, as centers of rural-oriented research, teaching and outreach. They were conceived of as "people's universities" and an "answer to elitism" (Mcdowell 2003, p. 33). The mandate of these institutions was to increase "access to knowledge" through both the classroom and an "outreach function" (McDowell 2003, p. 34). Since then, their outreach or extension function has provided an important institutional link between farmers, the university and the state (McDowell 2003; McLean 2007). The agricultural extension services are considered to have been an important driver of rural and agricultural development and transformation across the US. In the 1980s and 1990s funding for agricultural extension was reduced, like in Europe, as a result of broader reforms including privatization (Labarthe and Laurent 2013). One result of these changes was that farmers increasingly turned to private companies and consultants for information and advice (Bell et al. 2015; Charles 2017).

Influenced by new public management approaches, public extension services have also been asked to increase their accountability and improve the measurability of their impacts. In this context, Mahon et al. (2010, pp. 106-107) observed a "broader ongoing preoccupation of public extension services to remain relevant within agricultural policy discourses that are reflective of a global neoliberal agenda". According to McLean (2007), the public extension system was "once oriented toward social justice but is now oriented toward revenue generation and the marketplace" (p. 7) and has "lost its progressive role" (p. 8). Some critics have suggested that public extension is now part of an "academicindustrial complex" (Zimdahl 2013, p. 11) and that "agricultural education risks becoming a service industry, not for farmers and ranchers but for corporate interests" (Zimdahl 2003, p. 112). According to Colasanti et al. (2009, p. 2), this has "produced differential benefits and helped to stratify rural populations", and even resulted in "individual alienation from institutions designed to serve the public good".

An alternative view is that public extension in North America "has always had a complex relationship to broader political issues" as it adapted "to the predominant economic relations of the era" (McLean 2007, p. 18). Indeed, McLean shows how in western Canada extension "helped produce independent commodity producers in the early twentieth century, just as it helped produce wage laborers in the late twentieth century" (McLean 2007, p. 19). Extension services have thus either "struggled to engage with small-scale farmers and landless rural communities or actively collaborated with large-scale agricultural operations and financial institutions" (Liebman and Raskin 2016, p. 2). Similarly, some argue that academic-industrial "collaborations" can be considered as "just another manifestation of the utilitarian policy underlying the Morrill Act, the desire to create a more robust marketplace" (Stuart 2004, p. 1024). Extension however also exerts a certain "influence on the research agenda" (McDowell 2003, p. 36). Moreover, it still operates within a grey area between formal scientific knowledge and "objectivity" on the one hand, and local knowledge and "engagement" on the other, thus oscillating between an education and an advocacy role (Liebman and Raskin 2016).

Extension scientists work closely with the media, and especially the professional, agriculturally-focused media, which channel their discourses. Private sector media outlets play an important role in the diffusion of agricultural information and innovations (Evans and Heiberger 2016). It has even been suggested that they could be considered "the nations' largest non-formal program of continuing education for farmers, ranchers and their families" (Evans and Heiberger 2016, p. 94). Linked to broader changes in the media sector, agricultural media outlets have become more specialized and are increasingly grouped in networks, including print and online magazines and newspapers, as well as radio stations, television channels and mobile phone applications (Heiberger and Evans 2017). These networks are owned by private media groups that generate revenue from subscriptions and advertising (Evans and Heiberger 2016). One of them, the Farm Progress Group, dates back nearly 200 years and has been owned by the multinational events and publishing company Informa since 2016. It is a key player in US agriculture, covering a large part of the country with regional titles. Out of the 20 texts from agricultural magazines and newspapers analyzed in this study, 
eight were published in titles belonging to this group. Farm Progress also organizes the Farm Progress Show which is one of the oldest and the largest outdoor agricultural exhibitions in the US, with more than 600 exhibitors. ${ }^{5}$

Media outlets both produce and channel discourse about agriculture (Heiberger and Evans 2017). For example, in relation to the controversy around antibiotic resistance in agriculture in France, Badau (2016, p. 67, pers. trans.) showed that the agricultural media was "actively participating" in the discursive construction of the problem. The agricultural press also provides a platform for extension personnel to diffuse information: a survey of media coverage of farm safety found that agricultural journalists mainly looked to state extension personnel for information (Heiberger and Evans 2017).

Media interest in superweeds has however gone well beyond the specialized agricultural media. Extension scientists and other academics have been interviewed by and cited in US regional, national and in international media outlets. Although these outlets are not directed towards a farming audience, they amplify the superweed framing by diffusing it beyond the farming arena, and in the process, transform an agronomic problem into a society problem. In this case, framing and storylines do not aim at educating and influencing farmers' practices, but rather justifying to the broader society the actions and directions taken by the agricultural sector.

\section{Herbicide-resistant Palmer amaranth: the discursive production of a crisis}

The term "superweed" can be considered as a metaphor, calling on imaginaries of the superhero, with super powers. Generally, scientists and extension personnel, and the Weed Science Society of America, tend to avoid the term superweed considering it "slang" and misleading ${ }^{6}$ because it conflates herbicide-resistant weeds with a super plant in combat against herbicide (Bonny 2016, p. 43). Journalists, on the other hand are fond of the superweed metaphor, sometimes even using cartoons to portray resistant weeds as having the attributes of superheroes.

Political ecologists have studied the discursive construction of "environmental weeds" and "alien invasive species" as environmental problems (Kull and Rangan 2015), and the importance of metaphor in "biological invasion" discourses (Tassin and Kull 2012, p. 407, pers. trans.). They highlight the use of militaristic and combat-oriented metaphors (Bach

\footnotetext{
5 https://www.farmprogressshow.com/en/Attend.html, consulted on the 07.02.2019.

${ }^{6} \mathrm{http}: / /$ wssa.net/2015/04/weed-scientists-offer-new-definition-forsuperweed/, consulted on 20.12.2018.
}

and Larson 2017; Larson 2005, 2010; Tassin and Kull 2012), as well as medical (Baskin 2013; Tassin and Kull 2012), cultural and nationalist metaphors. To our knowledge, no study has yet analyzed the use of metaphorical language around agricultural weeds, and particularly the so-called superweeds. As detailed below, some of the metaphors we found are similar to the categories identified by Tassin and Kull (2012), and most notably those in the militaristic register. We however found other registers or "lexical reservoirs" (Larson et al. 2016) that also play important roles.

\section{The storyline and the key role of metaphor}

The problem of superweeds is framed by a storyline that starts in 2004, when a GM cotton grower in Georgia first reported that in one of his fields PA had survived an application of the herbicide Round-up. The following year, scientists from the University of Georgia demonstrated PA resistant to glyphosate and other herbicides (Culpepper et al. 2006; Ward 2013). This episode is the foundation story for superweed discourse, and is re-told often in agricultural and international media (Caulcutt 2009; redigerweb 2011; Smith 2011; Gallant 2013; Kistner 2018). Since then, the emergence and spread of HRPA is widely described in terms of "contamination" (appearing in 17 texts): "Palmer amaranth has spread from the south through contaminated feed, including cottonseed and hay" (Behnken et al. 2016). The term "infestation" (appearing in 25 texts) is also widely used by both scientists and journalists to describe its spread (Appendix See Table 4). These renderings construct HRPA as an epidemic, and as with other epidemics and pandemics, the origin story responds to the need of discovering where and when infection first appeared.

Just as it has become common to talk about "war" and "competition" in medical discourse, or "information" and "code" in genetic discourse (Nerlich 2009), it might be argued that contamination and infestation have become "obligatory passage points" (Callon et al. 2001) in superweed discourse (Larson et al. 2016). What is interesting in the specific case of superweed, is not only the widespread use of these terms, but how they are used to suggest an infestation that will be impossible to control (Appendix See Table 4). This is the second important storyline, which does not paint HRPA as just another weed, but rather as an existential threat that must be prioritized at all costs. This crisis storyline is empowered and "facilitated" (Hajer 2006) by the frequent use of negative metaphors.

Scientists and journalists all used fight or military metaphors in their reporting of HRPA. Terms such as "fight" (in three texts), "combat" (in two texts) or "battle" (in one text) were used in scientific reports and briefs. Other scientists resorted to fight metaphors when interviewed in the media: "They're winning the fight, they're winning the battle" as an 
Table 1 Links between metaphorical portrayal of herbicide resistant Palmer Amaranth and legitimated actions

\begin{tabular}{|c|c|}
\hline $\begin{array}{l}\text { Metaphorical por- } \\
\text { trayal of HRPA }\end{array}$ & Legitimated actions \\
\hline "Aggressive" & $\begin{array}{l}\text { Practices such as "aggressive tillage", with farmers encouraged to "aggressively stamp it [HPRA] out" and to "aggressively } \\
\text { manage it" }\end{array}$ \\
\hline "Diabolic" & Radical action, as one should not try to negotiate with the devil \\
\hline "A monstrosity" & Eradication, as opposed to controlling it or living with it \\
\hline "A scoundrel" & Should be given no mercy, appealing to morality \\
\hline "Ugly" & $\begin{array}{l}\text { Eradication by appealing to the "mutually recognized symbol" of "tidy fields" (Sutherland 2013, p. 431) and farmers' desire } \\
\text { for social recognition from their peers }\end{array}$ \\
\hline "Money-robbing" & $\begin{array}{l}\text { Eradication by appealing to economic rationality. Conversely, it would be irrational to oppose eradication of such a "profit } \\
\text { Siphon" }\end{array}$ \\
\hline
\end{tabular}

Illinois scientist told an Inquistr journalist (Dodrill 2015); while he is also reported to have said "Cold, hard steel is the only option in many cases. If you don't have any more bullets in your gun, you've got to pick up another tool" (Bennett 2013). Agricultural media also highlight the "fight" (in 6 texts), the "battle" (in 5 texts) and the "combat" (in 3 texts) of farmers and extension personnel against HRPA (Appendix See Table 4). Journalists from regional media use the terms "fight" (in 5 texts), "battle" (in three texts) and "combat" (in two texts) and depict farmers as "warriors" (Mayer 2014) who are "on the front lines" (Mayer 2014). HRPA is portrayed as "marching" (Eller 2017) through fields. Journalists writing for national and international media make use of the terms "assaulted" (Caulcutt 2009), "fight" (Dodrill 2015; Keim 2014; Koba 2014; Neuman and Pollack 2010; Young and Polansk 2017) and "combat" (Dodrill 2015).

In superweed discourse the characteristics of HRPA that make it adaptive - rapid growth, efficient reproduction, and ability to thrive in a range of environmental conditions - are a source of danger. Scientists portray HRPA as "aggressive" (in six texts) and "fierce" (in one text), while the term "aggressive" is also frequently used in the agricultural and regional media (in 13 texts) (Appendix See Table 4). HRPA has also been portrayed as a "nightmare" and a "bad dream" by scientists and journalists in agricultural media (Appendix See Table 4).

Both scientists and journalists commonly personify HRPA, suggesting it shares some of the worst features of humanity (Appendix See Table 4). A weed scientist was quoted in the media referring to HRPA as a "monster" (Smith 2015), and this term monster is also used by journalists in agricultural (Gallant 2013) and national media (Smith 2015). Journalists also refer to HRPA as a "zombie" weed (Smith 2015; SudOuest.fr 2015). On the Ohio State University Extension website HRPA is portrayed as showing its "ugly head" (Ohio State University 2016). Agricultural media presented HRPA as an "ugly weed" (Smith 2011). The image of ugliness is in tension with the view held by some farmers that the absence of weeds is a sign of beauty and "cleanliness" (Bennett 2011).

Others reach into a more demonic register to describe HRPA. For example, a weed scientist at the University of Illinois refers to HRPA as "Satan" (Bennett 2013; Gullickson 2017). In an article in American Agriculturist magazine, two scientists refer to HRPA as a "scourge" (Anderson and Hartzler 2017), and this term is also used by a journalist in regional media outlet (Meersman 2016). In Successful Farming magazine, a journalist considers HRPA as a "dark prince", a "spreader of evil", a "silent lurker of debauchery", a "weed demon", and goes on to compare it to a "sin". He concludes by enjoining farmers not to give up the fight because "most of the world's religions teach that, ultimately, good triumphs over evil. It's the same way with Palmer amaranth" (Gullickson 2017). In the international media HRPA has been portrayed as "the evil pigweed" and "Monsanto's bane" (Leonard 2008).

The superweed storyline also emphasizes the dramatic economic impacts HRPA has had, or will have. Scientists evoke "devastating yield loss" (Anderson and Hartzler 2017) and incorporate projections of the potential cost of "failing to properly fight" HRPA (University of Illinois 2014). The future is threatening (Appendix See Table 4). Metaphors - money-robbing, profit Siphon - are also used by both scientists (Hartzler and Anderson 2016; University of Illinois 2014) and journalists to portray the economic harm that farmers suffer at the hands of HRPA (Appendix See Table 4).

Overall, as these many examples demonstrate, both scientists and journalists frequently make use of negative metaphors. These go beyond registers of infestation and war to incorporate religion and morality, with the latter personifying HRPA as an enemy, a villain, a robber and a demon. This process has also been observed by Nerlich (2009) in relation to public and policy discourse about "superbugs" and antibiotic resistance. Metaphors like these induce responses either 
by calling on cultural references, or appealing to affects or rationalities (Table 1).

Communication scientists have however shown how negative metaphors can increase anxiety and create panic, and as a result, they can actually inhibit action. This might seem paradoxical in view of the urgency that is so central to the discourse. On the other hand, there is actually a strong underlying logic in this discouragement because, according to superweed framing, farmers are not expected to exercise their agency or act on their own knowledge or experience, but rather to turn quickly to the extension experts as the most legitimate source of help and guidance.

\section{Legitimate actors and others}

Through a variety of discursive processes, scientists, and especially those in an extension capacity, are legitimated as the principle actors for dealing with the superweed problem. Formal research to understand the mechanism of resistance and the efficacy of herbicides is highly valued. On the website of Kansas State University Research and Extension Service, researchers were presented as having made a "breakthrough toward understanding glyphosate resistance in pigweeds" (Kansas State University Extension 2018). An extension weed scientist says he and his colleagues have "saved" family farms (Gallant 2013), whereas journalist portrayed the scientists as "fighting" HRPA together with farmers (Gallant 2013), and "putting together plans to beat back the weed" (Aginfotoday 2016). Finally, scientists and journalists writing in the agricultural media explicitly advise farmers to turn to their extension agents, in order to identify HRPA (Davis and Recker 2014; North Dakota State University n.d.; PennState Extension n.d.; University of Kentucky 2015; Foster Seachrist 2016; Kistner 2018; Mohr 2017) and to develop "effective chemical management" (Kistner 2018). This both legitimizes extension's role and reproduces a "deficiency view of people [i.e. the farmers] who need a 'hero' to save them" (Colasanti et al. 2009, p. 2).

State government is also sometimes framed as a legitimate actor, for example, being expected to provide and finance a "battle plan" (Mohr 2017). This might translate into the expectation that affected states put PA on their noxious weed list (Aginfotoday 2016; Gullickson 2017) in order to have "authority and resources to immediately respond" (Gullickson 2017), "find and fight the weed" (Meersman 2016), and "enforce the state's noxious weed law to clear out the weeds before they spread" (Keck 2018). Minnesota is lauded for having acted quickly to add PA to its list (Aginfotoday 2016; Gullickson 2017; Meersman 2016). Some farmers however express concern about states' capacity to control HRPA (Bennett 2011). Federal authorities are also required to "send warning letters to farmers enrolled in conservation programs" and "provide technical help about how to manage weed-infested land" (Meersman 2016). Yet some scientists cited in Aginfotoday (2016) say they felt that "the federal government has been mostly silent". Later in 2017, the same scientist approved of a federal government decision to allow the use of herbicide to kill PA on conservation plots and to "share in some of the costs" (Eller 2017). For his part, a farmer cited in Eller (2014) "wants government regulators to approve new products from Dow and Monsanto to help battle the weed".

Normative statements such as "some growers who failed to recognize the threat lost their farms as a result" (University of Illinois 2014) promote the idea that farmers who "lost their farms" were deficient (or "bad"), while implicitly, "good" farmers did not or would not have lost their farms. This is reinforced by statements praising the work of individual (good) farmers, for example: "He is doing a great job at trying to prevent its spread in other fields and to eradicate it" (a weed scientist cited in Mayer (2014)).

Injunctions or "statements with [explicit] obligational modalities" (Chiapello and Fairclough 2002, p. 197) also appeared as an important linguistic feature in the texts we examined, particularly those from extension (24 times) and from agricultural media (23 times). Normative and prescriptive statement used modal verbs such as "should", "must" or "have to" and the imperative tense. These both help to legitimize the authors and their prescriptions, and to motivate the reader (Chiapello and Fairclough 2002, p. 199). This is particularly so if prescriptions and statements with obligational modalities are "categorical, unmitigated, not hedged" (Chiapello and Fairclough 2002, p. 200). These prescriptions were mostly directed towards farmers and less often towards government (Table 2).

Some injunctions were also indirectly addressed to famers using nominalizations such as: "If plants are found, they should be removed and destroyed. Above all, they should not be allowed to go to seed" (Behnken et al. 2016) (also see Appendix See Table 4). Injunctions with strong obligational modalities appear to converge towards "coupled principles of precaution and early intervention" as already observed by Tassin (2017, p. 426, pers. trans.), and practices of "aggressive" tillage and chemical control.

Prescriptions to use integrated weed management are generally constructed with a lower degree of obligation: "growers can adopt an integrated weed management program" (AGDAILY 2017, emphasis added). Some scientists do encourage farmers to "use the recommended integrated weed management strategies" (Kansas State University Extension 2018), not as a radical shift in weed management, but in order to "not lose the option of using glyphosate for the sustainability of our agriculture" (Kansas State University Extension 2018). Others call for a "robust Integrated Pest Management approach" (Davis and Recker 2014) but if PA is present, then farmers should adopt a " zero tolerance' 
Table 2 Common injunction within superweed discourse

\begin{tabular}{ll}
\hline Injunction & \\
\hline Farmers should feel & "worried" (Gullickson 2017; Mayer 2014) \\
"scared" (Eller 2014) & Not scared (Mohr 2017) \\
"vigilant" (weed scientist Jason Norsworthy interviewed in Mayer (2014)) \\
"pro- active" (Keck 2018; Kistner 2018; Mayer 2014) \\
"on alert" (Smith 2011) \\
"on the lookout" (Behnken et al. 2016; PennState University 2016) \\
"Educating yourself is the first step" (MDA's noxious weed program coor- \\
"dinator, cited in (Mohr 2017) \\
"learn[ing] how to identify" (Hartzler and Anderson 2016) \\
Practice[ing] herbicide and crop rotation (Kansas State University Exten- \\
sion 2018) \\
"climb[ing] 'on board' to fight Palmer" (Aginfotoday 2016) \\
"report[ing] infestations" (Mohr 2017) \\
"attempt[ing] to eradicate any Palmer amaranth found" (Behnken et al. \\
2016) \\
"Do[ing] whatever it takes to not allow new infestations to set seed" (exten- \\
sion weed scientist Dwight Lingenfelter, cited in (PennState University \\
2016) \\
"Aggressively control[ling] plants to prevent seed production and spread" \\
(PennState Extension n.d.)
\end{tabular}

mindset with eradication as the goal where feasible" (Davis and Recker 2014). Farmers are also enjoined to "use integrated management practices to aggressively control weeds" (PennState Extension n.d.). Thus, integrated practices, when mentioned, are portrayed using similar rhetoric, for example highlighting "aggressiveness", as that used to promote eradication. Notably, few of the texts from agricultural media mention integrated management (AGDAILY 2017; Kistner 2018). The implication is clear: at the end of the day farmers will bear responsibility for the infestation if, in spite of warning and prescriptions, they fail to eradicate the HRPA "scourge". This might produce normalization of particular farming practices and further control of farmers' actions, by redefining what it means to be a "good farmer" (see Burton et al. 2020).

\section{Discussion: effects of metaphors and injunctions}

A key finding from our analysis is the ambiguity of the discourse of extension scientists. On one hand they empathize with the farmers and draw attention to their needs, and openly advocate against the use of the alternative herbicide dicamba (Charles 2017; Dewey 2017). On the other hand, together with journalists, they form part of the coalition diffusing the framing, storylines and metaphors that have encouraged the use of aggressive if contested technology like dicamba and dicamba-resistant crop varieties. In a context of the "legitimacy crisis" of extension, we hypothesize that this indirect support of and contribution to superweed discourse might serve as a source of legitimation, open funding opportunities and help to maintaining extension's relevance.

Our research also demonstrates the repeated use of metaphor, by both scientists and journalists, to portray HRPA as evil and a scourge beyond the more common registers of infestation and war. The morality and religious registers help legitimate aggressive solutions, even when some of these may pose serious ethical questions like the potential sacrifice of non-human species (the weed themselves but also associated flora and fauna). Tassin (2017) has already pointed to the lack of open public debate around how best to balance the negative and positive impacts of the use of herbicide to "combat" environmental weeds. The debate around agricultural weeds is however not often framed in those terms.

If any doubt regarding the importance of eradication remained, money-robbing metaphors and reminders of the (potential) economic losses, appeal to economic rationality. The use of such registers, combined with normative statements cast doubt on the morality and irrationality of the farmers who would dare to take an option other than eradication.

Making the weed the enemy, as opposed to the technology (i.e. the herbicide and herbicide resistant crop combination) that produced the resistance, reinforces the technooptimism master frame (Dentzman et al. 2016). This is done by silencing possible counter-discourses, and delegitimizing alternative ways to manage HRPA, such as the use of IPM and agroecological methods (The Union of Concerned Scientists 2013). In the field of microbiology, Nerlich (2009) notes that the development of antibiotics with new modes of action (e.g. that do not kill bacteria but disable them) has been slow and might have been hindered by the war and 
fight framing that encouraged researchers and politicians to continue to fund research to develop new "killer" antibiotics. According to the NGO ETC Group, agro-chemical companies are considering the use of new "gene drive" technology to re-sensitize HRPA and other superweeds to glyphosate (ETC Group 2018). A ready-made discourse about the existential threats posed by superweeds and the need for radical solutions will certainly help to justify the use of this new technology, the safety of which is contested (ETC Group 2018).

Emphasizing the intensity and seriousness of the threat through storylines and metaphors that present HRPA, and superweeds generally, as too serious to be managed by "nonexperts" portrays farmers as "needing help" and may further increase their dependence on external experts. Such an outcome would feed into a dynamic of deskilling (Fitzgerald 1993 ) and may ultimately risk further "alienating the farmers from the land" (Bell et al. 2017, p. 310) as they become even more reliant on experts as generators and mediators of knowledge, and corporations as producers of packaged solutions.

Finally, weed scientists tend to believe that PA's herbicide resistance is a result of the "natural" laws of evolution as opposed to the plant's active resistance (hence the dislike the term superweed). However, the portrayal of PA as a monster, a devil or pernicious scoundrel resonates with the idea of the plant having agency and super capacities. Thus, in superweed discourse PA appears as an active subject in the "co-production of the biosphere" (Head et al. 2014, p. 399), instead of a passive object that should be "done to", even if those "capacities" are not considered as welcome. This recalls scholarship on unruly nature (Krishnan et al. 2015), that has a capacity to "transgress human expectations" (Govindrajan 2015, p. 37) and break human rules, with the suggestion that it reveals "a deep-seated belief that humans can and should dominate the world around them" (Krishnan et al. 2015, p. 7).

\section{Conclusion}

Herbicide resistant weeds, and superweed discourse, are now both deeply rooted in the Midwestern US. At the same time, the controversy continues over use of the herbicide dicamba combined with dicamba-resistant crop varieties. While farmers are increasingly using this combination, they may be doing so not out of conviction or faith, but out of fear (Charles 2019). In this context, our analysis highlights the importance of examining the discursive construction of agricultural problems by extension personnel and media outlets (i.e. going beyond the binary of activist and agribusiness discourses). We show that regardless of their intentions, weed scientists and the media give implicit support to superweed discourse, thus creating fear and potentially discouraging and deskilling farmers, while hindering new directions in weed management research and practice.

We show the crossing of a threshold between the discursive production of any everyday weed problem and that of a superweed. Indeed, the latter combines a crisis framing with an existential threat, heightened by the use of various metaphoric registers. Scott (2017) shows how domestication of wild plants and animals had a clear role in state building but has been justified and naturalized within a civilization narrative. This narrative contrasts domesticated plants, livestock and farming, with the "barbarous" and "savage" huntergatherers and their wild edibles. In this context, superweeds threaten not only the epistemic community of weed scientists, their worldview and the economic interests of agribusiness, but the civilization narrative and political institutions that underpin them. Thinking and speaking differently about weeds is a necessary first small step in changing the worldview of the epistemic community of mainstream weed scientists, and shifting the techno-optimism master frame. Technological lock-in that favors herbicide-centric approaches will make this extremely difficult, but according to Ward et al. (2014) only movement along these lines will open opportunities for truly innovative weed management strategies and practices.

\section{Appendix}

See Tables 3 and 4 
Table 3 Sources of examined texts

\begin{tabular}{|c|c|}
\hline Outlet type & Outlet \\
\hline Professional magazines and newspapers & $\begin{array}{l}\text { AgDaily } \\
\text { The Farmer } \\
\text { American Agriculturist } \\
\text { The Western Producer } \\
\text { Successful Farming } \\
\text { Southeast FarmPress } \\
\text { Ohio Farmer } \\
\text { Nebraska Farmer } \\
\text { Modern Farmer } \\
\text { Growing Produce } \\
\text { Farm and Dairy } \\
\text { Delta Farm Press (3x) } \\
\text { Dakota Farmer } \\
\text { Corn \& Soybean Digest } \\
\text { Agweek (2x) } \\
\text { AgWeb } \\
\text { AGinfotoday }\end{array}$ \\
\hline Agricultural extension & $\begin{array}{l}\text { Kansas State University, Research \& Extension } \\
\text { University of Kentucky, College of Agriculture, Food and Environment } \\
\text { Michigan State University Extension } \\
\text { North Dakota State University Extension } \\
\text { University of Wisconsin Crop and Weed Science Extension } \\
\text { University of Minnesota Extension } \\
\text { University of Illinois College of Agricultural, Consumer and Environmental Sciences } \\
\text { Extension (2x) } \\
\text { PennState University } \\
\text { PennState University Extension Unit } \\
\text { Ohio State University Extension } \\
\text { Iowa State University Extension and Outreach }(2 \mathrm{x}) \\
\text { University of Nebraska }\end{array}$ \\
\hline US national & $\begin{array}{l}\text { Salon } \\
\text { Wired } \\
\text { The New York Times } \\
\text { The Inquisitr } \\
\text { NBC } \\
\text { Vice News }\end{array}$ \\
\hline US regional & $\begin{array}{l}\text { NetNebraska } \\
\text { North Iowa Times } \\
\text { The Des Moines Register (2x) } \\
\text { Star Tribune (Minnesota) } \\
\text { The Daily Republic }\end{array}$ \\
\hline International & $\begin{array}{l}\text { The Scientist magazine } \\
\text { Bloomberg } \\
\text { Redigerweb } \\
\text { The Guardian } \\
\text { SudOuest.fr } \\
\text { Le Monde } \\
\text { Reuters }(2 x) \\
\text { Le Figaro } \\
\text { France } 24\end{array}$ \\
\hline
\end{tabular}


Table 4 Additional examples by theme

Theme Examples

Infestation and contamination

'Containing new infestations and preventing their spread is a critical first step to managing these new threats' (PennState Extension n.d.);

'To prevent further spread, work in areas where the weed is absent first and in infested areas last' (Kistner 2018)

HRPA contamination is impossible to control

'No matter how effectively you keep seed out, you can't prevent pollen movement. Once resistance arrives through pollen, the massive seed production of the female plant provides the avenue for glyphosate-resistant Palmer amaranth plants to take over the farm in as little as two year' (Georgia weed scientist, cited in Smith (2011))

An extension document presents HRPA as 'so tough to control' (Kaatz 2014)

In the agricultural media it is presented as 'especially difficult to control' (AGDAILY 2017)

Journalist Knutson (2017) says HRPA is something that can 'explode on you'

While for Gallant (2013), 'nothing could kill palmer'

Other journalists tell stories of farmers making 'desperate attempts to control the weed' (Aginfotoday 2016)

Some journalists in agricultural media (e.g. Lavicky 2014) and scientists (Anderson and Hartzler 2017; University of Kentucky 2015) insist that HRPA is still manageable but only if farmers strictly follow extension instructions

Dramatic economic impacts; a threatening future

'An invasive weed that has put some southern cotton farmers out of business is now finding its way across the Midwest' (University of Illinois 2014)

An Illinois scientist states that 'if you think about the value of agronomic row crops in this state, that's why we're very, very concerned about how devastating this could be to us', while for others, 'it's hard to imagine another weed species that would be more injurious to crop production than what this one will be' (University of Illinois at Urbana-Champaign 2014)

A Purdue University Extension Specialist states that: 'It's the only weed I've seen that can drive a farmer out of business' (North Dakota State University n.d.)

Journalists also paint a picture of threatened futures using the term 'catastrophe' (Robin 2009), asserting that HRPA 'has the power to choke the state's economy and environment' (Eller 2014), and that farmers will have to 'fight to keep the money-robbing pigweed from marching into millions of Iowa's crop acres' (Eller 2017)

Knutson (2017) reports the words of a farm representative in Nebraska, saying that HRPA is 'a train wreck waiting to happen'

Some journalists depict the 'superweed future' as going back 'to an era when hand choppers, residual herbicides, hooded sprayers and tillage were the tools of the weed control trade' (Robinson 2010). For Dodrill (2015), HRPA means 'going back to the old-fashioned method of hand weed pulling'

Military metaphors

'Arkansas farmer Tommy Young says Southern growers have lived through nearly a decade of torment, fighting a destructive, fast- growing weed that can carry a million seeds, grow as tall as an NBA player and is unfazed by several herbicides' (Eller 2014)

'Stanley Culpepper has spent most of the last decade fighting a monster' (Gallant 2013)

Farmers are portrayed as 'invaded' (Kistner 2018) by HRPA, itself portrayed as an 'enemy' (Gullickson 2017) 'march[ing]' through the fields (Aginfotoday 2016)

In this fight, farmers are 'armed' (Knutson 2017) with different 'weapons' (Cherveny 2017) like 'propane blow torches, herbicide, the sharp blades of mowers' (Cherveny 2017) in order to 'defeat' (Gallant 2013) HRPA

When HRPA 'wins the battle', it is portrayed as 'towering triumphantly' (Knutson 2017) in farmers' fields

Aggressiveness of HRPA

Scientists portray HRPA as 'the most competitive and aggressive of the pigweed species' (Kaatz 2014)

For journalist 'Palmer amaranth is an aggressive and destructive weed' (Foster Seachrist 2016)

Gallant (2013) refers to HRPA's 'seed-spreading ferocity'

Nightmare, bad dream and torment

'Just a few years ago, every cotton field in Georgia was a nightmare, he says, a bad dream that's since spread across the country' (weed scientist, in Gallant (2013)

It is 'tormenting' farmers (Davis and Recker 2014)

For one journalist, because of HRPA, farmers are living through 'torment' (Eller 2014) 
Table 4 (continued)

\begin{tabular}{|c|c|}
\hline Theme & Examples \\
\hline Negative personification & $\begin{array}{l}\text { Some scientists paint HRPA as 'pernicious' (North Dakota State University n.d.), provoca- } \\
\text { tively 'smiling at you' (North Carolina weed scientists in Roberson (2010) } \\
\text { Journalists also portrays the weed as 'ornery' (Smith 2011), 'wicked' (Gullickson 2017), a } \\
\text { 'villain' (Arnason 2017) and a 'scoundrel' (Arnason 2017; Gullickson 2017) } \\
\text { It also has 'rogue resistance' (Gullickson 2017) and a 'nasty reputation' (Arnason 2017), as } \\
\text { the 'bad brother' of waterhemp amaranth (Morrison 2016) }\end{array}$ \\
\hline Economic harm & $\begin{array}{l}\text { Journalists report on the economic harm ('prejudice') or damage (Koba 2014; Miserey 2012) } \\
\text { to crop yields 'biting into farmer's pocketbooks' (Coombs 2012) } \\
\text { Others portray HRPA as 'money-robbing' (Eller 2017), assert it is 'steal[ing] yields' (Gul- } \\
\text { lickson 2017) and portray it as a 'Profit Siphon' (Lavicky 2014) }\end{array}$ \\
\hline Injunctions using normalization & $\begin{array}{l}\text { 'Not a single plant should be tolerated' (University of Illinois 2014) } \\
\text { “"Zero tolerance” should be the weed control goal' (Knutson 2017) } \\
\text { 'A very aggressive pre-plant and/or pre- emergence program is essential to control glypho- } \\
\text { sate-resistant Palmer in cotton' (Robinson 2010) } \\
\text { 'Every single plant must be destroyed' (Keck 2018) }\end{array}$ \\
\hline
\end{tabular}

Acknowledgements We gratefully acknowledge the very helpful comments and suggestions of two anonymous reviewers.

Funding Open Access funding provided by Université de Lausanne.

Open Access This article is licensed under a Creative Commons Attribution 4.0 International License, which permits use, sharing, adaptation, distribution and reproduction in any medium or format, as long as you give appropriate credit to the original author(s) and the source, provide a link to the Creative Commons licence, and indicate if changes were made. The images or other third party material in this article are included in the article's Creative Commons licence, unless indicated otherwise in a credit line to the material. If material is not included in the article's Creative Commons licence and your intended use is not permitted by statutory regulation or exceeds the permitted use, you will need to obtain permission directly from the copyright holder. To view a copy of this licence, visit http://creativecommons.org/licenses/by/4.0/.

\section{References}

AGDAILY, 2017. Syngenta: Palmer amaranth will be biggest threat in 2017. AGDAILY, January 6. https://www.agdaily.com/crops/ syngenta-palmer-amaranth-threat-2017/. Accessed 31 July 2020.

Aginfotoday, 2016. Superweed palmer amaranth quickly spreading through Iowa. AGinfotoday, December 19.

Alemayehu, F., et al. 2015. The potential for utilizing the seed crop amaranth (Amaranthus spp.) in East Africa as an alternative crop to support food security and climate change mitigation. Journal of Agronomy and Crop Science 201: 321-329.

Anderson, M. and B. Hartzler. 2017. Palmer amaranth can be stopped [WWW Document]. American Agriculturist, 12 January. https:// www.americanagriculturist.com/weeds/palmer-amaranth-can-bestopped. Accessed 31 July 2020.

Andersson, J.A., and J. Sumberg. 2017. Knowledge politics in development-oriented agronomy. In Agronomy for development: The politics of knowledge in agricultural research, ed. J. Sumberg, 1-13. London and New York: Routledge.

Arnason, R. 2017. Palmer amaranth top weed villain. The Western Producer, June 8.
Bach, T.M., and B.M.H. Larson. 2017. Speaking about weeds: Indigenous elders' metaphors for invasive species and their management. Environmental Values 26: 561-581.

Badau, E. 2016. L'antibiorésistance à l'épreuve des discours de la presse agricole. Questions De Communication 29: 67-85.

Bain, C., et al. 2017. "Superweeds" or "survivors"? Framing the problem of glyphosate resistant weeds and genetically engineered crops. Journal of Rural Studies 51: 211-221.

Baskin, Y. 2013. A plague of rats and rubbervines: The growing threat of species invasions. Washington, DC: Island Press.

Behnken, L. et al. 2016. Palmer amaranth: A new weed threat to watch out for. University of Minnesota Extension, August 23. http:// blog-crop-news.extension.umn.edu/2016/08/palmer-amaranthnew-weed-threat-to.html. Accessed 31 July 2020.

Bell, K.L., et al. 2017. Chance long-distance or human-mediated dispersal? How Acacia s.l. farnesiana attained its pan-tropical distribution. Royal Society Open Science 4: 170105.

Bell, S.E., et al. 2015. Manipulated masculinities: Agribusiness, deskilling, and the rise of the businessman-farmer in the United States. Rural Sociology 80: 285-313.

Bennett, D. 2011. Dealing with resistant pigweeds in Arkansas' Clay County. Delta Farm Press, October 17.

Bennett, D. 2013. Weed resistance and new technologies. Delta Farm Press, August 23.

Bétrisey, F., and V. Boisvert. 2020. Amaranth's "Rediscovery" in Mexico: A path toward decolonization of food? In Critical approaches to superfoods, ed. E. McDonell and R. Wilk, 168186. London: Bloomsbury Academic.

Bonny, S. 2016. Genetically modified herbicide-tolerant crops, weeds, and herbicides: Overview and impact. Environmental Management 57: 31-48.

Breeze, R. 2017. Explaining superfoods: Exploring metaphor scenarios in media science reports. Ibérica: Revista De La Asociación Europea De Lenguas Para Fines Específicos (AELFE): 67-88.

Bruce, A. 2014. Amaranth revival - Mexican farmers rediscover an ancient superfood. The Ecologist, October 25.

Burton, R.J.F., et al. 2020. The good farmer: Culture and identity in food and agriculture. London: Routledge.

Callon, M., et al. 2001. Agir dans un monde incertain - Essai sur la démocratie technique. Paris: Seuil.

Caulcutt, C. 2009. Les 'super mauvaises herbes' menacent la patrie de Monsanto. France 24, April 19.

Charles, D. 2017. Monsanto attacks scientists after studies show trouble for weedkiller dicamba. National Public Radio, October 26. 
Charles, D. 2019. Is fear driving sales of Monsanto's dicamba-proof soybeans? NPR.org, February 7.

Cherveny, T. 2017. Minnesota keeps Palmer Amaranth at bay by pulling by hand, blow torching. Agweek, July 11.

Chiapello, E., and N. Fairclough. 2002. Understanding the new management ideology: A transdisciplinary contribution from critical discourse analysis and new sociology of capitalism. Discourse \& Society 13: 185-208.

Cochrane, W.W. 1958. Farm prices: Myth and reality. Minneapolis: University of Minnesota Press.

Colasanti, K., et al. 2009. Extension, the land-grant mission, and civic agriculture: Cultivating change. Journal of Extension 47(4): 4FEA1.

Coombs, A. 2012. Revenge of the weeds. The Scientist Magazine, May 20.

Culpepper, A.S., et al. 2006. Glyphosate-resistant Palmer amaranth (Amaranthus palmeri) confirmed in Georgia. Weed Science 54: 620-626.

Davis, V., and R. Recker. 2014. Palmer amaranth identified through the late-season weed escape survey [WWW Document]. Wisconsin Crop Weed Science. https://wcws.cals.wisc.edu/2014/01/ 15/palmer-amaranth-identified-through-the-late-season-weedescape-survey/. Accessed 31 July 2020.

Dentzman, K. 2018. 'I would say that might be all it is, is hope': The framing of herbicide resistance and how farmers explain their faith in herbicides. Journal of Rural Studies 57: 118-127.

Dentzman, K., et al. 2016. Techno-optimism as a barrier to overcoming herbicide resistance: Comparing farmer perceptions of the future potential of herbicides. Journal of Rural Studies 48: 22-32.

Dewey, C. 2017. This miracle weed killer was supposed to save farmers. Instead, it's devastating them. Washington Post, August 29.

Dodrill, T. 2015. Superweeds are winning the battle against farmers [WWW Document]. The Inquisitr, November 20. https://www. inquisitr.com/1726952/superweeds-are-winning-the-battle-again st-farmers/. Accessed 31 July 2020.

Eller, D. 2017. Iowa farmers battle to keep 'super weed' out of their corn and beans. The Des Moines Register, May 5.

Eller, D. 2014. 'Superweeds' choke farms. The Des Moines Register, June 22.

ETC Group. 2018. Forcing the farm: How gene drive organisms could entrench industrial agriculture and threaten food sovereignty. Val David, Canada: ETC Group.

Evans, J., and S. Heiberger. 2016. Agricultural media coverage of farm safety: Review of the literature. Journal of Agromedicine 21: 91-105.

Faber, S. 2017. Trapped on Monsanto's chemical treadmill: Dicamba debacle shows folly of herbicide arms race [WWW Document]. Environmental Working Group, August 30. https://www.ewg.org/ agmag/2017/08/trapped-monsanto-s-chemical-treadmill-dicam ba-debacle-shows-folly-herbicide-arms-race. Accessed 31 July 2020.

Fairclough, N. 2013. Critical discourse analysis and critical policy studies. Critical Policy Studies 7: 177-197.

Fairhead, J., et al. 2012. Anthropogenic dark earths and Africa: A political agronomy of research disjunctures. In Contested agronomy: Agricultural research in a changing world, eds. Sumberg, J. and J. Thompson, J. New York/London: Earthscan/Routledge.

Fitzgerald, D. 1993. Farmers deskilled: Hybrid corn and farmers' work. Technology and Culture 34: 324-343.

Flitter, E. 2017. Special report: The decisions behind Monsanto's weedkiller crisis. Reuters, November 9.

Forsyth, T. 2003. Critical political ecology: The politics of environmental science. London: Routledge.

Foster Seachrist, K. 2016. Palmer amaranth: Find it, stop it. Farm and Dairy, March 9.
Foyer, J. 2010. Il était une fois la bio-révolution. Paris: Presses Universitaires de France.

Gallant, A. 2013. Pigweed in the cotton: A 'superweed' invades Georgia. Modern Farmer, July 18. https://modernfarmer.com/2013/ 07/superweeds-2/. Accessed 31 July 2020.

Goldman, M.J., et al. 2011. Knowing nature: Conversations at the intersection of political ecology and science studies. Chicago and London: University of Chicago Press.

Govindrajan, R. 2015. The man-eater sent by god: Unruly interspecies intimacies in India's Central Himalayas. RCC Perspectives 3: 33-38.

Gullickson, G. 2017. Defeating palmer amaranth. Palmer amaranth: Bedeviling farmers like no other weed. Successful Farming, May

Gullón, B., et al. 2016. Assessment of the prebiotic effect of quinoa and amaranth in the human intestinal ecosystem. Food \& Function 7 (9): 3782-3788.

Hajer, M.A. 1995. The politics of environmental discourse: Ecological modernization and the policy process. Oxford and New York: Clarendon Press.

Hajer, M.A. 2006. Doing discourse analysis: Coalitions, practices, meaning. In Words matter in policy and planning: Discourse theory and method in the social sciences, ed. M. van den Brink and T. Metze, 65-74. Utrecht: Netherland Geographical Institute.

Hartzler, B. and M. Anderson. 2016. Palmer amaranth on the move [WWW Document]. Iowa State University - Extension and Outreach, July 21. https://crops.extension.iastate.edu/cropnews/ 2016/07/palmer-amaranth-move. Accessed 31 July 2020.

Head, L., et al. 2014. The distinctive capacities of plants: Re-thinking difference via invasive species. Transactions of the Institute of British GeographeRS 40: 399-413.

Heap, I. 2021. The International Herbicide-Resistant Weed Database. Online at www.weedscience.org, July 31.

Heiberger, S., and J.F. Evans. 2017. New extension approaches to serving agricultural media in advancing farm-life safety communications. Journal of Extension 55(6): 6RIB3.

Hilton, H.W. 1957. Herbicide tolerant strains of weeds. Hawaiian Sugar Plant Association. Annual Report, p 69. Honolulu: University of Hawaii.

Kaatz, P. 2014. Palmer amaranth will cause challenges for forage producers [WWW Document]. MSU Extension, February 13. https://www.canr.msu.edu/news/palmer_amaranth_will_cause_ challenges_for_forage_producers. Accessed 31 July 2020.

Kansas State University Extension. 2018. Kansas State University researchers make breakthrough toward understanding glyphosate resistance in pigweeds [WWW Document]. $K$-State Research and Extension News, March 12. http://www.ksre.k-state.edu/news/ stories/2018/03/glyphosate-resistance-pigweed.html. Accessed July 2020.

Keck, G. 2018. Patrolling for Palmer amaranth. Ohio Farmer, March 27.

Keim, B. 2014. The next generation of gm crops has arrived - and so has the controversy. WIRED, June 24.

Keulartz, J. 2007. Using metaphors in restoring nature. Nature and Culture 2: 27-48.

Kistner, E.J. 2018. Superweed palmer amaranth is on the move: here's what you need to know. Growing Produce, April 4. http://www. growingproduce.com/vegetables/superweed-palmer-amaranthmove-heres-need-know/. Accessed 31 July 2020.

Knutson, J. 2017. Forewarned, forearmed: Preparing to fight Palmer amaranth. Agweek, August 28.

Koba, M. 2014. 'Superweeds' sprout farmland controversy over GMOs. NBC News, September 30.

Koteyko, N., et al. 2010. From carbon markets to carbon morality: Creative compounds as framing devices in online discourses on climate change mitigation. Science Communication 32: 25-54. 
Krishnan, S., et al. 2015. Introduction: Unruly matters. RCC Perspectives 3 : 5-8.

Kull, C.A. 2018. Critical invasion science: Weeds, pests, and aliens, In The Palgrave handbook of critical physical geography, eds. Lave, R., Biermann, C., and S. Lane, 249-272. Cham, Switzerland: Palgrave Macmillan.

Kull, C.A., and H. Rangan. 2015. The political ecology of weeds: A scalar approach to landscape transformations. In The international handbook of political ecology, ed. R.L. Bryant, 487-500. Cheltenham, UK: Edward Elgar Publishing.

Labarthe, P., and C. Laurent. 2013. Privatization of agricultural extension services in the EU: Towards a lack of adequate knowledge for small-scale farms? Food Policy 38: 240-252.

Larson, B. 2005. The war of the roses: Demilitarizing invasion biology. Frontiers in Ecology and the Environment 3: 495-500.

Larson, B. 2010. Reweaving narratives about humans and invasive species. Études Rurales 185: 25-38.

Larson, B. 2014. Metaphors for environmental sustainability: Redefining our relationship with nature. New Haven and London: Yale University Press.

Larson, B., et al. 2016. Metaphors and biorisks: The war on infectious diseases and invasive species. Science Communication 26 (3): 243-268.

Lavicky, J. 2014. Palmer amaranth: Understanding the profit siphon in your field [WWW Document]. Dakota Farmer, July 24. https:// www.dakotafarmer.com/whitepaper-palmer-amaranth-under standing-profit-siphon-field-16. Accessed 31 July 2020.

Leipold, S., and G. Winkel. 2016. Divide and conquer - Discursive agency in the politics of illegal logging in the United States. Global Environmental Change 36: 35-45.

Leonard, A. 2008. Monsanto's bane: The evil pigweed. Salon.com, August 27.

Liebman, A., and D. Raskin. 2016. 'Extension(al)' crisis: University of Minnesota Extension and Urban Food Movements in Minneapolis. Paper presented at 'Contested Agronomy: Whose Agronomy Counts?', Institute of Development Studies, Brighton, UK.

Maasen, S., and P. Weingart. 2000. Metaphor and the dynamics of knowledge. London and New York: Routledge.

Mahon, M., et al. 2010. Power, positionality and the view from within: Agricultural advisers' role in implementing participatory extension programmes in the Republic of Ireland. Sociologia Ruralis 50: $104-120$.

Mayer, A. 2014. On front lines, farmers struggle against chemicalresistant weeds. The Gazette, July 31 .

McAfee, K. 2003. Neoliberalism on the molecular scale. Economic and genetic reductionism in biotechnology battles. Geoforum 34: 203-219.

McDowell, G.R. 2003. Engaged universities: Lessons from the landgrant universities and extension. The annals of the American Academy of Political and Social Science 585: 31-50.

McLean, S. 2007. University extension and social change: Positioning a university of the people in Saskatchewan. Adult Education Quarterly 58: 3-21.

Meersman, T. 2016. Superweed introduced to Minnesota with conservation seed mix. Star Tribune, December 28.

Milner, C. 2015. Science loves this superfood, so why aren't you eating it? The Epoch Times, March 5. www.theepochtimes.com.

Miserey, Y. 2012. Les OGM ont perdu la guerre contre les mauvaises herbes. Le Figaro.

Mohr, P. 2017. Minnesota's battle plan for Palmer [WWW Document]. The Farmer, January 24. https://www.the-farmer.com/weeds/ minnesota-s-battle-plan-palmer. Accessed 31 July 2020.

Morrison, L. 2016. Early detection, intensive management can stop Palmer amaranth [WWW Document]. Corn and Soybean Digest, January 15. https://www.cornandsoybeandigest.com/crop-chemi cals/early-detection-intensive-management-can-stop-palmeramaranth. Accessed 31 July 2020.

Nerlich, B. 2009. 'The post-antibiotic apocalypse' and the 'war on superbugs': Catastrophe discourse in microbiology, its rhetorical form and political function. Public Understanding of Science 18: 574-590.

Neuman, W. and A. Pollack. 2010. U.S. Farmers Cope with RoundupResistant Weeds. The New York Times, 3 May,

North Dakota State University. n.d. Palmer Amaranth [WWW Document]. https://www.ag.ndsu.edu/palmeramaranth. Accessed 31 July 2020.

Ohio State University. 2016. New Palmer amaranth finds - we're mowing down soybean fields folks [WWW Document]. OSU Weed Management, August 18. http://u.osu.edu/osuweeds/2016/08/18/ new-palmer-amaranth-finds-were-mowing-down-soybean-fieldsfolks/. Accessed 31 July 2020.

Oxford English Dictionary. “metaphor, $n$ ”. Oxford: Oxford University Press.

PennState Extension. n.d. Invasive pigweeds: Palmer amaranth and waterhemp [WWW Document]. Penn State University. https:// extension.psu.edu/invasive-pigweeds-palmer-amaranth-andwaterhemp. Accessed 31 July 2020.

PennState University. 2016. Growers cautioned to be on the lookout for invasive pigweeds [WWW Document]. PennState University. https://news.psu.edu/story/407153/2016/04/27/research/growerscautioned-be-lookout-invasive-pigweeds. Accessed 31 July 2020.

redigerweb. 2011. Une délicieuse mauvaise herbe, l'amarante, défie Monsanto et son herbicide le Roundup. Exercices et formation en techniques d'écriture, stages pour journalistes et écrivains. https://redigerweb.wordpress.com/2011/12/02/une-delicieusemauvaise-herbe-lamarante-defie-monsanto-et-son-herbicide-leroundup/. Accessed 31 July 2020.

Robin, M-M. 2009. Les 'super mauvaises herbes' envahissent l'Amérique. Le blog de Marie-Monique Robin. https://archives. m2rfilms.com/2009/04/. Accessed 20 Aug 2020.

Robinson, E. 2010. Zero tolerance for resistant pigweed. Delta Farm Press, August 30.

Roberson, R. 2010. Palmer amaranth 'super weed.' Southeast FarmPress, October 18.

Scott, J.C. 2017. Against the grain: A deep history of the earliest states. New Haven: Yale University Press.

Smith, M. 2015. Four decades of herbicide use is creating zombie weeds that just won't die. Vice News, September 24. https://news. vice.com/article/four-decades-of-herbicide-use-is-creating-zombie-weeds-that-just-wont-die. Accessed 31 July 2020.

Smith, P. 2011. The truth about pigweed [WWW Document]. AgWeb - The Home Page of Agriculture. https://www.agweb.com/artic le/the_truth_about_pigweed/. Accessed 31 July 2020.

Sparks, B. 2014. New problems, new day. Journal of Extension 52(2): 2 COM1.

Stibbe, A. 2001. Language, power and the social construction of animals. Society and Animals 9: 145-161.

Stuart, J. 2004. The academic-industrial complex: A warning to universities. University of Colorado Law Review 75: 1011-1064.

SudOuest.fr. 2015. Etats-Unis: les mauvaises herbes "zombies" pullulent dans les champs d'OGM. SudOuest.fr, September 30.

Sumberg, J., ed. 2017. Agronomy for development: The politics of knowledge in agricultural research. London and New York: Routledge.

Sumberg, J., et al. 2013. Why agronomy in the developing world has become contentious. Agriculture and Human Values 30: 71-83.

Sumberg, J., et al. 2014. Political agronomy. In Encyclopedia of food and agricultural ethics, ed. D. Kaplan. Dordrecht: Springer.

Sutherland, L.A. 2013. Can organic farmers be "good farmers"? Adding the "taste of necessity" to the conventionalization debate. Agriculture and Human Values 30 (3): 429-441. 
Tassin, J. 2017. User de pesticides pour contrôler les espèces invasives: Les facettes d'un paradoxe éthique. Revue D'ecoloGIE (terre Et Vie) 72 (4): 425-438.

Tassin, J., and C. Kull. 2012. Pour une autre représentation métaphorique des invasions biologiques. Natures Sciences SociétéS 20: 404-414.

The Union of Concerned Scientists. 2013. The rise of superweeds - and what to do about it (Policy Brief). Cambridge, MA: The Union of Concerned Scientists.

Turnhout, E. 2018. The politics of environmental knowledge. Conservation and Society 16: 363-371.

University of Illinois. 2014. Palmer amaranth threatens Midwest farm economy, researchers report [WWW Document]. Science Daily, June 3. https://www.sciencedaily.com/releases/2014/06/14060 3114323.htm. Accessed 31 July 2020.

University of Kentucky. 2015. Palmer amaranth and waterhemp continues to expand across Kentucky [WWW Document]. University of Kentucky, College of Agriculture, Food and Environment. http://weedscience.ca.uky.edu/news-story/palmer-amaranth-andwaterhemp-continues-expand-across-kentucky. Accessed 31 July 2020.

Vicari, S. 2015. Construction de l'ethos d'autorité dans les discours de l'Académie. Mots. Les Langages Du Politique 107: 19-33.

Ward, L. 2013. Eco-governmentality revisited: Mapping divergent subjectivities among integrated water resource management experts in Paraguay. Geoforum 46: 91-102.

Ward, S.M., et al. 2014. Agricultural weed research: A critique and two proposals. Weed Science 62: 672-678.

Ward, S.M., T.M. Webster, and L.E. Steckel. 2013. Palmer amaranth (Amaranthus palmeri): A review. Weed Technology 27: 12-27.

Westengen, O.T., et al. 2018. A climate for commerce: The political agronomy of conservation agriculture in Zambia. Agriculture and Human Values 35: 255-268.

Young, R. and T. Polansk. 2017. Destructive weed threatens U.S. corn fields. Reuters, April 5.
Zimdahl, R.L. 2003. The mission of land grant colleges of agriculture. American Journal of Alternative AgriculturE 18: 103-115.

Zimdahl, R.L. 2013. Fundamentals of weed science. London: Academic Press.

Publisher's Note Springer Nature remains neutral with regard to jurisdictional claims in published maps and institutional affiliations.

Florence Bétrisey is Junior Lecturer at the Institute of Geography and Sustainability (IGD), Faculty of Geosciences and Environment, University of Lausanne, Switzerland. She works on institutional arrangements in the agro-environmental field and the role that scientific and local knowledges play in these arrangements. Her current research concerns the valuation of agrobiodiversity and farmer know-how.

Valérie Boisvert is Professor at the Institute of Geography and Sustainability (IGD), Faculty of Geosciences and Environment, University of Lausanne, Switzerland. Her work focuses on the political economy of biodiversity, the valuation of wild plants and local landraces, and the development of biodiversity-related markets. Her current research concerns agrobiodiversity management in the context of agroecology and alternative agricultures.

James Sumberg is Emeritus Fellow in the Rural Futures research group at the Institute of Development Studies (IDS), Brighton UK. He is an agriculturalist by training, and since 1982 has focused primarily on sub-Saharan Africa. Over the last decade his main research interests have been the politics of knowledge in agricultural research and youth engagement in African rural economies. 